\title{
Developing English materials for English for tourism
}

\author{
Muhamad Argi Afriandi a,1, Nur Fatimah b,2* \\ a,b Universitas Ahmad Dahlan, Jl. Ringroad Selatan, Kragilan, Tamanan, Kec. Banguntapan, Bantul, Daerah Istimewa Yogyakarta 55191, Indonesia \\ 1 mhdargiafriandi@gmail.com; 2 nur.fatimah@pbi.uad.ac.id* \\ *corresponding author
}

\section{ARTICLE INFO}

Article history

Received 24 December 2019

Revised 14 March 2020

Accepted 10 August 2020

Available Online 15 January 2021

\section{Keywords}

research and development

develop

English materials

English for tourism

\begin{abstract}
The potential of tourism industry increases every year. The tourism sector is believed to be able to create centers of economic growth of the country. One of the institutions that play a role in tourism industry is English Education Department, Universitas Ahmad Dahlan. This department cooperates with several tourism partners to train the students about tourism. There are two subjects about tourism named English for Tourism and Practicum on Tourism. The problem emerged from the students and materials. The students of English for Tourism lack of vocabulary and speaking. They need specific materials (textbook) for learning English about tourism. The materials of English for Tourism should be developed. Therefore, the objectives of the study are (1) developing English materials for English for Tourism; (2) finding out the possible English developed materials for English for Tourism. This study is research and development. The steps are identifying potentials and problems, collecting the data, product design, product validation, product revision and product trial. The data were obtained from an instrument of which validation was from an expert of material, instrument expert. The validated instrument was used for subject trial assessment. The subject of this research was the students of English for Tourism. Simple random sampling was used in this study. In composing the materials, the needs from the previous research by Effendi and Khafidhoh (2018) were one to consider in addition to the existing syllabus of English for Tourism in English Education Department. The product of this research is English developed materials (textbook) for English for Tourism. The total score of expert material's validation is $82 \%$, it shows that the developed materials are excellent. The mean of subject trial assessment is $82.94 \%$, it shows that the product is excellent. The mean of the score validation and subject trial assessment is $82.47 \%$, it is an excellent product.
\end{abstract}

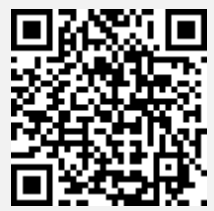

This is an open access article under the CC-BY-SA license.

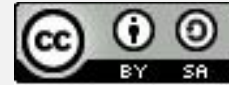

\section{Introduction}

English is an important language for many purposes. It became the accepted international language of technology and commerce. It created a new generation of learners who know specifically why they were learning a language-businessmen and-women who wanted to sell their products, mechanic who had to read the journals, doctors who needed to keep up with developments in their field and a whole range of students whose course of study included textbooks 
and journals only available in English (Hutchinson \& Waters, 1987). People use English for many things including traveling.

Travel has become the new life style of people. People travel around the world, including going to Indonesian tourism places such as Yogyakarta, Bali, Papua and so on. People travel for business, learning the culture or new thing, building the relationship with friends or family, celebrating an event, doing some adventure activities, relaxing, and others.

As one of the highest tourism countries in the world, Indonesia offers culture, beautiful landscape, the amazing underwater world, food and drink, spectacular mountains, historical places, ancient buildings, animals and plants, friendly and welcoming people and others. It impacts the tourism industry in Indonesia. Tourism industry becomes the new idol job sector in Indonesia. Tourism has an important role for the economics of Indonesia, it is one of the sources of foreign exchange income. It provides jobs, also offers the entrepreneur opportunity. It can be seen by the performance of tourism. It increases every year than the other industries such as gas, oil, coal and palm oil. Liputan6.com stated the tourism industry is the most sustainable commodity that touches the community into the low level of society. There is a significant increase of tourists in Indonesia every year. It was stated by Cahyu (2018), the foreign exchange contribution came to 16.8 billion US Dollar. Furthermore, the tourism sector is believed to be able to create centers economic growth in the country.

With the increasing need for tourism in all fields, it influences people to enter the tourism sector such as the establishment of new tourism objects, English language courses, expertise in tour guides, cafes and restaurants and more.

One of the institutions that play a role in the tourism industry is English Education Department in Universitas Ahmad Dahlan. This department cooperates with several tourism partners to train the students about tourism. The Head of PBI (English Education Department) said that the alumni of PBI will not only be a teacher but they can work in translation and tourism industry. Some of the alumni are the tour guides, even some make their own travel company. English Education Department in Universitas Ahmad Dahlan makes two subjects for tourism. Those are English for Tourism and Practicum on Tourism. English for Tourism is for 6 semester students and Practicum on Tourism is for 7 semester students as stated in Pedoman Akademik (2005).

Although the students of English for Tourism learn tourism in class but there is no specific material about training or practicing English in tourism. There is no text book about English for Tourism. The students get the materials on book and other references but they are all theoretical. The students need a learning practice about tourism. The students have little vocabulary to communicate with foreigners or tourists. They do not know how to communicate well in tourism. They also lack speaking skill. The tourism students do not know about specific information about tourism such as how to communicate with foreigners, giving suggestions about tourism places, and others. Tourism students need a specific book for learning English in tourism as they use it to communicate with foreigners and for business. Furthermore, the learning outcome should be developed into possibility materials.

Thus, the research on developing the materials for English for Tourism was conducted. The objectives are (1) to develop English materials for English for Tourism of English Education Department Universitas Ahmad Dahlan. (2) to find out the possible English developed materials for English for Tourism of English Education Department Universitas Ahmad Dahlan.

\section{Research Method}

\subsection{Research Design}

The research design is Research and Development (R\&D). R\&D is highly recommended to be conducted in an educational setting to facilitate educational development. R\&D is used to make a specific product and test the product (Sugiyono, 2018). The researchers also use the definition of ESP to make the materials. ESP is an approach to language learning, which is based on learner needs. It is an approach to language teaching in which all decisions as to content and method are based on the learner's reason for learning. ESP aims to make students know where they can use the English after they finish their learning process. English for Specific Purposes is an approach in 
language teaching in which the content and method clearly depend on the learners' needs and interests (Hutchinson and Waters, 1987; Cahyo et al, 2019; Fatimah, 2018).

There are 6 steps in research R\&D that the researchers only applied in the study. They are (1) identifying potential and problems (2) collecting data (3) product design (4) product validation (5) product revision (6) product trial.

The product trial was conducted after the validation instrument from an expert of instrument. The design trial was conducted after a review from an expert material (textbook).

\subsection{Subject of the Research}

The research involved students of English Education Department. The subjects of the product trial are 10 students of English for Tourism class. The technique of the subject trial is simple random sampling. The sample is selected randomly from the total population. It is stated that the researchers collected the subject data by sampling the population because of the limitation of cost of the research, energy and time. The subjects of this research are selected randomly. Every student of English for Tourism has an equal chance of being selected as a subject of this research.

\subsection{Instruments and Validity}

The researchers used questionnaires. Questionnaire is a number of written questions addressed to the respondents to obtain information about the respondent himself or other things that the respondent knows (Arikunto, 2002). In this research, the questionnaires were divided into three groups specifically (1) material feasibility test instrument (checklist textbook evaluation), (2) Instrument validation and (3) trial instrument.

In relation to the trial, this product trial used qualitative and quantitative data. The qualitative data were obtained from instrument validation from the expert of material, expert of instrument and subject trial instrument. Each of the instruments i.e. the one of the expert material and subject trial has closed and open questions. The instrument of expert instrument only included open questions. The qualitative data were based on the opened questions. The quantitative data were based on the closed questions. The qualitative data were based on the feedback and suggestions of the expert instrument, and subject trial. The quantitative data were obtained from expert product validation and the subject trial assessment. The quantitative data were collected by calculating the score of expert validation and subject trial assessment.

\section{Findings and Discussion}

\subsection{Findings}

Potential came from the newspaper about tourism potential in Indonesia. It was stated on Liputan6.com (Cahyu, 2018). There is a significant increase of tourists in Indonesia every year. Indonesia's tourism sector is projected to be able to contribute gross domestic product. Furthermore, the tourism sector is believed to be able to create centers economic growth in the country. The problems came from the interview of the students of English Education Department Universitas Ahmad Dahlan. Based on the interview, the researchers concluded that the students of English for Tourism are lacking in vocabulary and speaking. The students need a specific materials (textbook) for learning English about tourism and the Materials of English for Tourism should be developed.

The researchers took the data from the previous researchers (Effendi \& Khafidhoh, 2018). The researchers cooperated with the previous researchers. The previous researchers analyzed the needs of the students and the material for English for Tourism and Practicum of Tourism class. The research also made the materials based on the current syllabus of English for Tourism.

The product design contains the specification of the product. It includes the cover design, amount of page, the contents and the material. The details are (a) the cover design of the product and each chapter are about tourism industry, the cover design, picture and page design are unique and interesting, (b) the product was a textbook for English for Tourism, (c) the product consisted of 14 chapters, the materials provide the syllabus of English for Tourism. It is for 14 meetings of the class. (d) each chapter consisted of around 5 pages, (e) each chapter consisted of introduction, 
materials, exercises, summary and reference, (f) Each chapter had vocabulary list and professional practice.

The results of the expert material validation assessment are the values obtained on the results of the validation of the English for Tourism material and the product, it was conducted on Monday, May 13, 2019. The researchers use the design validation of checklist textbook evaluation from Mukundan (Nimehchisalem \& Mukundan, 2015). The percentage calculation of result of the assessment in the validation sheet from the material expert is the final score. It indicates the level of feasibility of the materials to use as suggested by Arikunto (2010).

$$
\begin{aligned}
\mathrm{P}=\frac{s}{N} \frac{s}{N} & \times{ }_{100} \\
& =\frac{86}{104} \times 100 \frac{86}{104} \times 100=82 \%
\end{aligned}
$$

Description:

$\mathrm{P}=$ Level of feasibility

$\mathrm{S}=$ The total number of scores obtained

$\mathrm{N}=$ Maximum number of scores

After the validation process, there are two suggestions from the expert but they are for further improvement. First, it is suggested to add more exercises in every chapter. It could be from easiest to the most difficult. The exercises should also be centered on the language skills. Second, the cost and teacher's guide book are recommended to consider.

In relation to the result of validation, based on the expert validation, it can be said that the product is excellent with the final score's $82 \%$. Therefore, the expert gives the result that the material (textbook) is worth using according to the validation. Table 1 shows the result of the instrument expert's validation.

\begin{tabular}{|c|c|c|}
\hline No & Items & Revision \\
\hline 1. & $\begin{array}{l}\text { Component of learning } \\
\text { comprehension }\end{array}$ & - \\
\hline 2. & $\begin{array}{l}\text { Component of materials } \\
\text { suitability }\end{array}$ & $\begin{array}{l}\text { Add the questionnaire questions: } \\
\text { a. The material is appropriate with the times. } \\
\text { b. The material is complete according to the syllabus. } \\
\text { c. The material is developed in accordance with the principle of tourism. }\end{array}$ \\
\hline 3. & $\begin{array}{l}\text { Component of language } \\
\text { feasibility }\end{array}$ & $\begin{array}{l}\text { Add the questionnaire questions: } \\
\text { a. The material is suitable with the level of students. } \\
\text { b. The material is simple, communicative, and interactive. }\end{array}$ \\
\hline 4. & $\begin{array}{l}\text { Component of presentation } \\
\text { feasibility }\end{array}$ & $\begin{array}{l}\text { Add the questionnaire questions: } \\
\text { a. The material is easy to use. } \\
\text { b. The material has diverse exercises. } \\
\text { c. The material has an answer key. } \\
\text { d. The material has feedback to the students. } \\
\text { e. The material has a clear instruction of each exercise. } \\
\text { f. The material has glossary. } \\
\text { g. The material has bibliography. }\end{array}$ \\
\hline 5. & Component of material activity & $\begin{array}{l}\text { Add the questionnaire questions: } \\
\text { The material has good illustration quality and is well printed. }\end{array}$ \\
\hline
\end{tabular}

Table 1. Result of Instrument Expert's Validation

Another finding is the need to put the questionnaire about tourism principle if there are tourism principle questions. Moreover, based on the expert validation, the material (textbook) is worth using according to the revision. 
After the product has been validated, it is stated that it is feasible for the subject trial. It was tested on 10 students of English Education Department of Universitas Ahmad Dahlan. After the class, the students were asked to assess the product and give a score on the questionnaire. The result of students' assessment on developed material (textbook) is presented in Table 2.

Table 2. Result of Subject Trial Assessment

\begin{tabular}{ccc}
\hline Students & Score & Category \\
\hline 1 & $90.17 \%$ & Excellent \\
2 & $81.25 \%$ & Excellent \\
3 & $86.60 \%$ & Excellent \\
4 & $78.57 \%$ & Good \\
5 & $74.10 \%$ & Good \\
6 & $88.39 \%$ & Excellent \\
7 & $82.28 \%$ & Excellent \\
8 & $90.17 \%$ & Excellent \\
9 & $70.53 \%$ & Good \\
10 & $80.35 \%$ & Excellent \\
Mean & $82.94 \%$ & Excellent \\
\hline
\end{tabular}

Some of the students give comments and suggestions. The exercises should consist of the answer key, the exercise should add the interesting game, the illustration should be more interesting and helping, the cover should put the subject of the book or the readers, the font is boring and too tight and the font should be tighter among the character of the word.

From the result of the subject trial, it can be stated that the product is feasible with a percentage of $82.48 \%$. It is included in the excellent score.

There are several comments and suggestions for the revision of the developed material (textbook) from the expert on material (textbook). It is decided for the recent study that the comments and suggestions for revision can be for further research. The expert on material said if the researchers did not do the revision for the point on defining the price, still the textbook is good enough. Further, responding to the comment and suggestions from the expert on instrument (validator), it is considered unnecessary to make immediate revision on that point (price of the textbook) in the questionnaire under the consideration for subject trial.

The material (textbook) of English for Tourism then has been developed and tested. The checklist used is Mukundan's textbook evaluation checklist (Nimehchisalem \& Mukundan, 2015), the material was validated by the expert on material. After the material has been stated appropriate material, it was tried out for the subject trial. Table 3 shows the result.

Table 3. The Result of the Developed Materials

\begin{tabular}{clcc}
\hline No & \multicolumn{1}{c}{ Evaluator } & Percentage & Category \\
\hline 1 & Expert on materials (textbook) & $82 \%$ & Excellent \\
2 & Students & $82.94 \%$ & Excellent \\
& Mean & $82.47 \%$ & Excellent \\
\hline
\end{tabular}

Based on the result of the material (textbook) and students' response, it can be stated that the developed material (textbook) is feasible to use. There is no major revision for the developed material. The comment and suggestion from the expert material (textbook) will be followed up on the further research since it is in relation to the price for the textbook to use for classroom practice, additional exercises for the users and teacher's guide in using the materials.

\subsection{Discussion}

The designed materials for English for Tourism were composed in such a way considering the learner and learning needs (Hutchinson \& Waters, 1987; Fatimah, 2018; Effendi \& Khafidhoh, 2018). Regarding the potentials on tourism and students' lack in speaking and vocabulary, the 
materials are produced for classroom practice, especially the classes of English for Tourism. As the result of this study, the materials contain 14 chapters in which each includes introduction, materials, exercises, summary and reference. Each chapter has a vocabulary list and professional practice. Therefore, the materials produced are theoretically and practically beneficial.

The materials are topic based. Some of the topics are on the tourism industry, culture gap in tourism, and dealing with guests. Moreover, the materials concern language expressions commonly used for tourism (such as describing something, giving steps on how to do something, expressing politeness).

Referring to the checklist on textbook evaluation (Nimehchisalem \& Mukundan, 2015), the product of this research is classified excellent by the experts, subjects (students). The product can be used for English for Tourism class of English Education Department of Universitas Ahmad Dahlan.

There are previous studies that show similarities and differences to this study. There were five studies investigating English materials for tourism. The first research was conducted by Ulfa (2015). This research focused on designing English Specific Purpose Materials for Akademi Pariwisata Medan. The objective of this study was finding out the student's need of English materials and to design the new English materials for tourism which were relevant to the needs especially for the middle class of Manajemen Usaha Perjalanan (MUP) in Akademi Pariwisata Medan. The study showed that the method used Research and Development (R\&D) by Borg and Gall (1983). It consisted of 10 steps of research. The researcher used questionnaire, interview, and documents. The sources of this research were English lecturers of Manajemen Usaha perjalanan (MUP) and $6^{\text {th }}$ semester students of MUP. The result of the study was the new materials based on students' needs. The materials created an effective learning by doing communicative language teaching.

The second research was conducted by Wardhani (2013). The title of the research was "Designing the Syllabus of English for Tourism 1 Subject." The objective of this research was finding necessary topics relevant to prospective graduate's jobs. It focused on the syllabus for English in tourism 1. The researcher distributed questionnaires with the random sampling method to 600 alumni in which only 100 of them gave responses. The results of this research were the developed syllabus and sample materials.

The third research was conducted by Herlina (2009). It focused on "English Materials Development for the First Grade Senior High School Students Based on Local Potency of Culture and Tourism in Wonosobo." This research focused on culture and tourism in English. This research included the curriculum and syllabus of the school in 2009.

The fourth research was conducted by Kuwumardani \& Kurniasih (2016). The title of this research was "Materials Development of English for Specific Purpose (ESP) for Tourism Program at SMKN 6 Surabaya." This research focused on exploring the contents of English materials based on the need analysis in the Tourism Program at SMKN 6 Surabaya and finding out the teacher's response toward the English materials development in the Tourism Program. This research used a descriptive qualitative method. The result showed that speaking and pronunciation language skill and component should be included in materials and teaching techniques. The result of this research was that English materials consisted of the presentations, several videos to practice speaking, pronunciation and vocabulary, reading passages and texts, and some knowledge for tourism.

The fifth research was conducted by Silalahi et al (2017). The title of the research is "Developing English Listening Materials for the Tenth Grade Students of Tourism Major in Vocational School." The objective of the research was finding out the appropriate English learning materials for students in tourism major. The method of this research was Research and Development $(\mathrm{R} \& \mathrm{D})$. This research used questionnaire and interview. The result of the research was the English listening materials for the tenth grade of tourism major.

Thus, it is clear that the recent and previous relevant studies show similarities and differences. Some points in common are on the objective, research method and the instrument(s). The differences are mainly on the materials developed and the learners or subjects. It is the evidence that the results of the studies produce the materials for English language teaching and learning. 


\section{Conclusion}

The research and development of the researchers used 6 steps of research and development. The steps were potentials and problems, collecting data, product design, product validation, product revision and product trial. The product of the research is developed material (textbook) for English for Tourism of English Education Department, Universitas Ahmad Dahlan.

The product of the research is feasible to use for the students of English for Tourism. The product could help the students to understand the material theoretically and practically. The total score of product assessment is $82 \%$ from the expert material and $82.94 \%$ from subject trial. The mean of the score is $82.47 \%$, it is an excellent product. Therefore, the materials on English for Tourism are recommended to use in English classes on tourism.

The more products for English for Tourism, the more opportunity for the learners and teachers to get access to the materials to learn and to teach. Further studies and more researchers including student researchers will be of significance to improve the availability and quality of materials of English for Tourism.

\section{References}

Akademik, Biro Administrasi. (2005). Pedoman akademik. Yogyakarta: Universitas Ahmad Dahlan.

Arikunto, S. (2002). Prosedur suatu penelitian: Pendekatan praktek edisi revisi kelima. Jakarta: Penerbit Rineka Cipta.

Arikunto, S. (2010). Prosedur penelitian: Suatu pendekatan praktik. Jakarta: PT Rineka Cipta.

Borg, W. R. and Gall, M. D. (1983). Educational research: An introduction. New York: Longman

Cahyo, S.D., Muslim, M.R.U., Rahman, A.N., \& Pratolo, B.W. (2019). Needs analysis of Islamic-based English reading material for the Muhammadiyah junior high school. International Journal of Evaluation and Research in Education, 9(2), 286-292.

Cahyu. (2018). Industri pariwisata kian meningkat pesat. Retrieved March 1, 2019, from www.liputan6.com: https://www.liputan6.com/lifestyle/read/3650849/industri-pariwisata-indonesia-kian-meningkat-pesat

Effendi, M., \& Khafidhoh. (2018). Analisis kebutuhan pada mata kuliah Practicum on Tourism. Yogyakarta: Pendidikan Bahasa Inggris Universitas Ahmad Dahlan.

Fatimah N. (2018). Students' needs for academic writing at the English Education Department. English Language Teaching Educational Journal, 1(3), 161-75.

Herlina, R. (2009). English material development for the first grade senior high school students based on local potency of culture and tourism in Wonosobo. Yogyakarta: Universitas Ahmad Dahlan.

Hutchinson, T., \& Waters, A. (1987). English for specific purposes. Cambridge: Cambridge University Press.

Kusumawardani, T. \& Kurniasih, E. (2016). Material development of English for specific purposes (ESP) for tourism program at SMKN 6 Surabaya. RETAIN 4(1), 1-11.

Nimehchisalem, V. \& Mukundan, J. (2015). Refinement of the English language teaching textbook evaluation checklist. Pertanika Journal of Social Sciences \& Humanities (23)4, 761-780.

Silalahi, S. C., Husein, R., \& Saragih, A. (2017). Developing English listening material for the tenth grade student of tourism major in vocational school. Genre Journal of Applied Linguistics of FBS UNIMED, (6)1, 1-17.

Sugiyono. (2018). Metode penelitian pendidikan pendekatan kuantitatif, kualitatif, dan R\&D. Bandung: Alfabeta.

Ulfa, K. (2015). Designing English specific purpose material for Akademi Pariwisata Medan. Pelita Informatika Budi Darma, (9)2, 69-75

Wardhani, Z. C. (2013). Designing the syllabus of English for tourism 1 subject. Surabaya: Widya Mandala Catholic University. 